\title{
As novas fronteiras em expansão
}

Quando a expansão maxilar foi inicialmente proposta $^{1,2}$, Angell chocou a comunidade odontológica com a sugestão de que as maxilas poderiam ser abertas por meio de um aparelho preso aos dentes. Suas inferências de que os ossos se movimentavam calcaram-se no diastema maxilar mediano que se abrira e que foi relatado em seu artigo. $\mathrm{O}$ mesmo foi relatado mas não demonstrado, pois a ilustração do diastema entre os incisivos centrais foi alterada pelo editor da revista - o espaço foi fechado -, pois esse não acreditava que aquilo era possível.

É provável que o rechaçamento às suas ideias tenha inibido o desenvolvimento dessa técnica ainda no século 19. Em verdade, foi necessário um século até que Andrew Haas reapresentasse esse conceito - por meio de um trabalho em animais ${ }^{3}$ e, logo a seguir, em humanos ${ }^{4}$. Após isso, a expansão maxilar disseminou-se para os consultórios ortodônticos do mundo inteiro. Poucas inovações tiveram tanto impacto em nossa especialidade.

A despeito de seus quase 50 anos de uso contínuo, o procedimento ainda tem o que ser explorado, e isso fez com que comemorássemos o $13^{\circ}$ aniversário da Revista com um número dedicado ao assunto. Esses novos horizontes podem ser vistos em vários artigos da presente edição, os quais proporcionarão ao leitor um claro panorama sobre o tema.

A palavra expansão tem origem no latim e significa estender, abrir, desdobrar. Esse número comemorativo representa, em si, uma expansão da Revista. Dois editores adjuntos integram, a partir de agora, nosso quadro principal de colaboradores. Eles estão entre os grandes nomes da Ortodontia brasileira e desempenharão importantes tarefas dentro da Revista.

O Prof. David Normando, da Universidade Federal do Pará, será o Editor Adjunto de Odontologia Baseada em Evidências. Ele trará para nossas páginas seu excepcional conhecimento sobre estatística e metodologia científica, ajudando no processo de aprimoramento dos trabalhos que serão publicados.

A Profa. Daniela Gamba Garib, da Faculdade de Odontologia de Bauru/HRAC-USP, será a Editora Adjunta para Artigos Online. Ela usará seu elevado conhecimento científico e tecnológico para selecionar os trabalhos mais sensíveis ao passar do tempo e publicá-los nessa seção, a qual é vital para o contínuo aprimoramento da Revista. Isso dará mais agilidade ao processo de publicação dos trabalhos.

Essas mudanças serão rapidamente perceptíveis e visam oferecer a vocês, leitores e autores, a melhor informação possível.

Leia sempre e expanda -indefinidamente - seus limites.

Jorge Faber

Editor chefe

faber@dentalpress.com.br

\section{REFERÊNCIAS}

1. ANGELL, E. H. Treatment of irregularity of the permanent or adult teeth. Part 1. Dental Cosmos, Philadelphia, v. 1, no. 10, p. 540-544, May 1860.

2. ANGELL, E. H. Treatment of irregularity of the permanent or adult teeth. Part 2. Dental Cosmos, Philadelphia, v. 1, no. 10, p. 599-600, June 1860.

3. HAAS, A. J. Rapid expansion of the maxillary dental arch and nasal cavity by opening the midpalatal suture. Angle Orthod., Appleton, v. 31, no. 2, p. 73-90, Apr. 1961.

4. HAAS, A. J. Palatal expansion: Just the beginning of dentofacial orthopedics. Am. J. Orthod., St. Louis, v. 57, no. 3, p. 219-255, Mar. 1970. 